\title{
Frequency and distribution of microsatellites from ESTs of citrus
}

\author{
Darío Abel Palmieri ${ }^{1 *}$, Valdenice Moreira Novelli ${ }^{{ }^{*}}$, Marinês Bastianel ${ }^{1 *}$, Mariângela Cristofani-Yaly ${ }^{{ }^{*}}$, \\ Gustavo Astúa-Monge ${ }^{1}$, Eduardo Fermino Carlos $^{1}$, Antonio Carlos de Oliveira ${ }^{2}$ and \\ Marcos Antonio Machado ${ }^{1}$ \\ ${ }^{1}$ Centro APTA Citros Sylvio Moreira, Instituto Agronômico de Campinas, Cordeirópolis, SP, Brazil. \\ ${ }^{2}$ Departamento de Ciências Naturais, Universidade Estadual Sudoeste da Bahia, \\ Campus Vitória da Conquista, Vitória da Conquista, BA, Brazil.
}

\begin{abstract}
Nearly 65,000 citrus EST (Expressed Sequence Tags) have been investigated using the CitEST project database. Microsatellites were investigated in the unigene sequences from Citrus spp. and Poncirus trifoliata. From these sequences, approximately $35 \%$ of the non-redundant ESTs contained SSRs. The frequencies of different SSR motifs were similar between Citrus spp and trifoliate orange. In general, mononucleotide repeats appeared to be the most abundant SSRs in the CitEST database, but we also identify di-, tri-, tetra-, penta- and hexanucleotide repeats. The AG/CT and AAG/CTT were the most common dinucleotide and trinucleotide motifs, with frequencies of $54.4 \%$ and $25.2 \%$, respectively. Primer sequences flanking SSR motifs were successfully designed and synthesized. After in silico polymorphism analysis, a subset of sixty-eight primers was validated in different Citrus spp. and Poncirus trifoliata. PCR-amplification revealed polymorphism in citrus with all tested primer pairs and showed the potential of these markers for linkage mapping. Our study showed that the CitEST database can be exploited for the development of SSR markers that can amplify Citrus spp. and related genus for comparative mapping and other genetic analyses.
\end{abstract}

Key words: Citrus spp., Poncirus trifoliata, ESTs, microsatellites, in silico polymorphism.

Received: July 21, 2006; Accepted: February 13, 2007.

\section{Introduction}

Microsatellites, or simple sequence repeats (SSR), are arrays of hypervariable short (1-5 bp) repeat motifs that can be found in both coding and non-coding DNA sequence of higher organisms. These single-locus markers are mainly characterized by high frequency, Mendelian inheritance and codominance. During the last decade, microsatellites have proven to be the marker of choice in plant genetics and breeding research, because of their variability, ease of use, accessibility of detection and reproducibility (Zane et al., 2002). There are now many well-known examples of initiatives using microsatellites for different plant species, including Citrus sp. (Kijas et al., 1994; Holton et al., 2002, Kantety et al., 2002, Cristofani et al., 2003).

Microsatellites are Polymerase Chain Reaction (PCR) based, requiring previous sequence identification, primer designing for the conserved flanking regions and

Send corresponcence to Mariângela Cristofani-Yaly. Laboratório de Biotecnologia, Centro APTA Citros Sylvio Moreira, Instituto Agronômico de Campinas, Rodovia Anhanguera km 158, Caixa Postal 4, 13490-970 Cordeirópolis, SP, Brazil. E-mail: mariangela@ centrodecitricultura.br.

${ }^{*}$ These authors contributed equally to the article. amplification of the target repeat. Initially, they were expensive to perform, and library enrichment protocols were widely used to reduce investments. However, new sources of microsatellites have been utilized, which are based on large genome sequencing projects. This was initially limited to species where databanks existed, but the increase in available DNA sequence information, particularly ESTs (expressed sequence tags), has provided new opportunities for development of molecular markers for several annual and perennial plant species. Examples are available for Arabidopsis (Delseny et al., 1997), grape (Scott et al., 2000), cereals (Kantety et al., 2002), eucalyptus (Ceresini et al., 2005) and others. More recently in citrus, microsatellites were investigated and characterized from public EST-database (Chen et al., 2006; Dong et al., 2006).

Microsatellites based on EST libraries (EST-SSRs) are powerful tools for genetic research in genetic variation, gene tagging and evolution, mapping and analysis of quantitative traits (Cato et al., 2001; Scott, 2001; Holton et al., 2002). In addition, microsatellites can also be used across species (Scott et al., 2000). EST-derived microsatellites have been observed to have high conserved flanking sequences among related species. This characteristic can be 
used to build comparative maps, identify orthologous loci and map genes of known function, such as genes controlling agronomic traits of interest (Kantety et al., 2002; Varshney et al., 2002). Although EST-derived SSRs have been shown to be less polymorphic than those derived from genomic sequences, they have some inherent advantages: quickly obtained by electronic sorting, unbiased in their repeat type, present in gene rich regions of the genome, and normally abundant (Scott, 2001).

Our laboratory, 'Centro APTA Citros Sylvio Moreira,' has developed a large citrus EST (CitEST) database, using libraries that represent different physiological conditions and citrus species. Because of the large number of sequences available from the CitEST project, this database was used to search for hypervariable motifs, such as microsatellites. Although most citrus types exhibit clear morphological variation among them, mainly within genus and species, many agronomical traits are difficult to select by conventional techniques, making assistance by molecular markers highly desirable. A potential reason for that is because most of the wanted traits are apparently quantitatively inherited (Cristofani et al., 2003; Novelli et al., 2006). Therefore, in this study, we mined the CitEST database searching for microsatellites, using an in silico approach for marker development, and an in vivo validation of candidate polymorphic markers. We developed a bioinformatic tool, named MarkerXplorer, which uses several publicly available software programs to retrieve and characterize microsatellite loci from the database. Different citrus genotypes, including a zygotic progeny from Rangpur lime (Citrus limonia Osbeck) vs. Swingle citrumelo (Citrus paradisi Macf. x P. trifoliata), were used to validate a set of markers developed in this study.

\section{Material and Methods}

\section{The CitEST database}

The 'Centro APTA Citros Sylvio Moreira' has a project to create and maintain a databank based on ESTs (CitEST) from different physiological conditions and also from different genera and species of citrus. The total number of sequences available is an constantly changing, but up to the date of this study, 171,430 citrus ESTs from different genotypes such as: Citrus aurantium L. - sour orange (CA), C. sinensis (L.) Osbeck - Pera sweet orange (CS), C. latifolia Tan. - Tahiti lime (LT), C. reticulata Blanco Ponkan mandarin (CR), C. aurantifolia (Christm) Swingle - Mexican lime (CG), C. limonia Osb. - Rangpur lime (CL) and P. trifoliata (L.) Raf. - trifoliata orange (PT) were analyzed (http://biotecnologia.centrodecitricultura.br/).

\section{Sorting sequences through a pipeline}

MarkerXplorer pipeline uses several scripts and executable programs such as MISA (MIcroSAtellite identification tool) - (Thiel et al., 2003), Primer3 (Rozen and Ska- letsky, 2000), and e-PCR (Schuler, 1997), and Perl scripts to identify repeated sequences, to design specific primer pairs and to evaluate, a priori, potential polymorphic markers. To avoid redundancy on further analysis, a clustering analysis with CAP3 software (Huang and Madan, 1999) was previously performed, and the MarkerXplorer pipeline was then used to run from a multi-FASTA formatted file containing 64,726 assembled sequences representing $54,492 \mathrm{~kb}$.

\section{Microsatellite search}

The adjusted parameters for our pipeline looked for mononucleotides motifs larger than 10 repeat units and all other repeats (di-, tri-, tetra-, penta- and hexanucleotides) larger than five repeat units. To identify the relative position of a SSR within a given sequence we used the strategy adapted by Ceresini et al. (2005) that categorized the microsatellites as initial (I, close to the 5' end), middle (M) or end (E, close to the 3' end). Mononucleotides were excluded from this analysis.

\section{Primer design}

One of MarkerXplorer output files was a tab-delimited file with all primer pairs flanking sequences nearby the microsatellite. The length of the amplicons was set to 100-350 bp. Oligonucleotide parameters for Primer3 were set to a length of 18-27 bp with an optimum of $20 \mathrm{bp}$, a GC content of $20 \%-80 \%$ with an optimum of $50 \%$, a melting temperature (Tm) of $57-63{ }^{\circ} \mathrm{C}$ with an optimum of $60{ }^{\circ} \mathrm{C}$, and a primer $\mathrm{Tm}$ maximum difference of $1{ }^{\circ} \mathrm{C}$. From a list of nearly 2,000 potential EST-SSR markers, 68 primer pairs were selected randomly and synthesized by IDT (Coralville, IA, USA) and tested. These oligonucleotides were resuspended to $100 \mu \mathrm{M}$ and tested on all different genotypes described below.

\section{Citrus progeny}

For primer validation, plant samples were obtained from the germplasm collection of the 'Centro APTA Citros Sylvio Moreira', Cordeirópolis, SP, Brazil, representing the following citrus genotypes: Pera sweet orange, Murcott tangor $(C$. sinensis x $C$. reticulata), Cravo mandarin $(C$. reticulata), Sunki mandarin (C. sunki Hort. ex. Tan.), Trifoliata orange, pummelo (C. grandis Osbeck), Rangpur lime, Swingle Citrumelo (C. paradisi Macf. x P. trifoliata) and a zygotic progeny from Rangpur lime vs. Citrumelo Swingle. DNA extraction was performed following the method described by Murray and Thompson (1980).

\section{Amplification and analysis of microsatellite loci}

PCRs were performed in a final volume of $25 \mu \mathrm{L}$, and the reactions contained $2.5 \mu \mathrm{L}$ of $10 \mathrm{X}$ Buffer $(100 \mathrm{mM}$ Tris-HCl pH 8.3; $500 \mathrm{mM} \mathrm{KCl} ; 25 \mathrm{mM} \mathrm{MgCl}_{2} ; 0.01 \%$ gelatin) (Invitrogen, São Paulo, Brazil), $200 \mu \mathrm{M}$ of each dNTP (Invitrogen), 4 pmol of each primer (forward and reverse), 
100-150 ng of genomic DNA and 1.0 unit of Taq DNA polymerase (Invitrogen). The amplification was performed using a touchdown program (TD1) which was set up to run 30 cycles of $30 \mathrm{~s}$ at $94{ }^{\circ} \mathrm{C}, 30 \mathrm{~s}$ at $65-56{ }^{\circ} \mathrm{C}$ (touchdown $0.3^{\circ} \mathrm{C}$ every cycle) and $5 \mathrm{~s}$ at $72{ }^{\circ} \mathrm{C}$. Amplification products were resolved on $4 \%$ agarose gels (TAE $1 \mathrm{X}$ ), containing $0.5 \mathrm{ng} / \mathrm{mL}$ of ethidium bromide.

\section{Functional characterization}

Functional annotation of Citrus markers was obtained from GenBank using blastX algorithm against $\mathrm{nr}$ database (Altschul et al., 1997) and further classified by gene ontology (Ashburner et al., 2000). GO Terms were extracted from the best homologous hit. The AmiGO term browser was used to find molecular function, cellular component and biological process ontology for these sequences.

\section{Results}

\section{Frequency and distribution of EST-SSRs in the CitEST database}

Using the MarkerXplorer pipeline, we obtained a detailed analysis of the frequency and distribution of all mono-, di-, tri-, tetra-, penta- and hexanucleotides repeats from the six Citrus and one Poncirus species. A set of 64,726 clustered sequences, with average length ranging from 586-bp (CL) to 891-bp (CS), were screened and 21,584 sequences $(33.3 \%)$ containing 27,656 non-redundant SSRs were identified (Table 1). Considering that approximately $54.5 \mathrm{Mb}$ were analyzed, we detected a frequency of at least $1 \mathrm{SSR}$ per $1.97 \mathrm{~kb}$ in the expressed fraction of citrus genome. From the number of SSR-containing sequences we observed an average frequency of $22.3 \%$ of sequences containing more than $1 \mathrm{SSR}$, with $C$. sinensis and $P$. trifoliata showing the highest frequencies, 24.0 and $23.4 \%$, respectively (Table 1 ).

Of those EST-SSRs identified by MarkerXplorer pipeline, 3,030 (10.9\%) were represented by compound microsatellites. Despite the differences in the total number of examined sequences among the seven species, frequencies of compound microsatellites were very similar, ranging from $9.7 \%$ in C. aurantium to $11.6 \%$ in C. sinensis (Table 1).

The most frequent microsatellite types were mononucleotide repeats in all seven studied species. Among the other repeats, di- and trinucleotides showed the highest frequencies for all species, ranging from $4.9 \%$ in C. limonia to $22.2 \%$ in C. sinensis and $2.2 \%$ in C. limonia to $11.4 \%$ in $C$. sinensis, respectively. Tetra-, penta- and hexanucleotide repeats were represented in proportions of 0.3 to $0.9 \%, 0.05$ to $0.2 \%$ and 0.15 to $0.3 \%$, respectively (Table 2 ).

Among the mononucleotide repeats, the motif $\mathrm{A} / \mathrm{T}$ was the most common (87.3\%) followed by $\mathrm{C} / \mathrm{G}(12.7 \%)$. The AG/CT and AT/AT motifs were the most common dinucleotide repeats with $54.4 \%$ and $22.3 \%$, respectively.

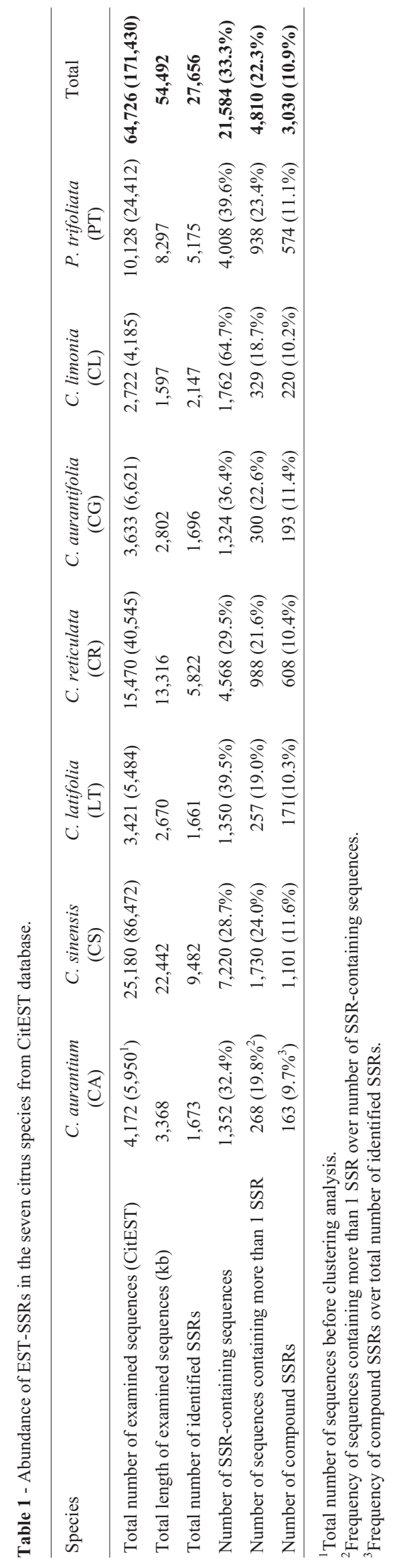


Table 2 - Frequency distribution (\%) of EST-SSRs based on motif size for each species. Numbers within parentheses represent absolute number of microsatellites.

\begin{tabular}{lcccccccc}
\hline & CA & CS & LT & CR & CG & CL & PT & Total per class \\
\hline Mononucleotide & $76.2(1,275)$ & $65.1(6,175)$ & $80.8(1,342)$ & $69.2(4,030)$ & $73.2(1,242)$ & $92.4(1,985)$ & $79.8(4,132)$ & 20,181 \\
Dinucleotide & $15.5(260)$ & $22.2(2,103)$ & $13.3(221)$ & $19.0(1,109)$ & $17.2(291)$ & $4.9(106)$ & $12.6(651)$ & 4,741 \\
Trinucleotide & $7.3(122)$ & $11.4(1,085)$ & $5.1(84)$ & $10.8(626)$ & $8.6(146)$ & $2.2(47)$ & $6.9(356)$ & 2,466 \\
Tetranucleotide & $0.6(10)$ & $0.9(83)$ & $0.5(09)$ & $0.7(41)$ & $0.6(10)$ & $0.05(01)$ & $0.4(23)$ & 177 \\
Pentanucleotide & $0.1(01)$ & $0.15(12)$ & $0.1(02)$ & $0.05(02)$ & $0.2(03)$ & $0.3(06)$ & $0.1(05)$ & 31 \\
Hexanucleotide & $0.3(05)$ & $0.25(24)$ & $0.2(03)$ & $0.25(14)$ & $0.2(04)$ & $0.15(02)$ & $0.2(08)$ & 60 \\
\hline
\end{tabular}

For tri- and tetranucleotides, the motifs $\mathrm{AAG} / \mathrm{CTT}$ reached $25.2 \%$, AAT/ATT $18.4 \%$, AAAT/ATTT $33.0 \%$, and AAAG/CTTT $22.5 \%$, being the most frequent repeats. The remaining penta- and hexanucleotide repeats were represented by AAAAT/ATTTT (19.2\%) and AACTC/AGTTG (23.1\%), AACACC/GGTTGT and ACGAGG/CCTGCT $(8.5 \%)$, respectively (Figure 1 ).

To obtain a more detailed analysis of the SSR structure, we used the categorization proposed by Weber (1990) in three classes: pure or perfect repeats, e.g., (AT) $)_{\mathrm{n}}$ or $(\mathrm{CTG})_{\mathrm{n}}$; imperfect repeats, e.g., $(\mathrm{TG})_{\mathrm{n}}(\mathrm{N})_{\mathrm{x}}(\mathrm{TG})_{\mathrm{m}}$ or $(\mathrm{GGC})_{\mathrm{n}}(\mathrm{N})_{\mathrm{x}}(\mathrm{GGC})_{\mathrm{m}}$, and compound repeats, e.g., $(\mathrm{GT})_{\mathrm{n}}(\mathrm{AT})_{\mathrm{m}},(\mathrm{ATC})_{\mathrm{n}}(\mathrm{GCG})_{\mathrm{m}}$ or $(\mathrm{CG})_{\mathrm{n}}(\mathrm{AAT})_{\mathrm{m}}$. For the seven citrus species, we observed a proportion of $89.1 \%$ of perfect, $7.2 \%$ of compound and $3.7 \%$ of imperfect repeats. When considering only perfect repeats, we observed variations in the number of repeat units per microsatellite type and species. The maximal length of the six SSR types ranged from 77 (C. latifolia) to 148 (P. trifoliata) units for mononucleotides; 20 (C. limonia) to 34 (C. sinensis) units for dinucleotides; 11 (C. aurantium) to 28 (C. sinensis) units for trinucleotides; six (C. limonia) to (11) units for tetranucleotides; five (C. reticulata) to nine ( $C$. sinensis) units for pentanucleotides; and six (C. aurantium, C. limonia and $P$. trifoliata) to 13 (C. reticulata) units for hexanucleotides.

We also examined and labeled the relative position of di-, tri-, tetra-, penta and hexanucleotides repeats identified by MarkerXplorer from the seven species. From this analysis we identified that about $58.0 \%$ of all microsatellites are localized closer to the $5^{\prime}$ ' end (I), while $23.0 \%$ are positioned near the 3 ' end (E) and $19.0 \%$ are distributed along

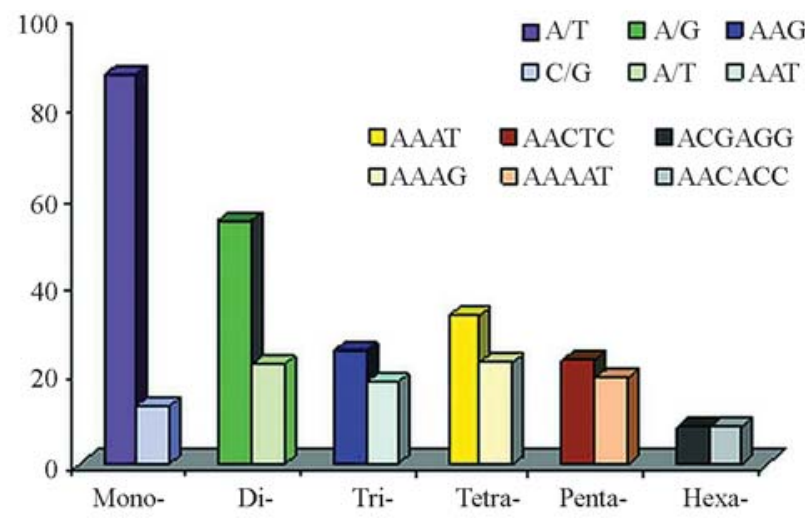

Figure 1 - Frequency of the most common SSR motifs in CitEST database.

the middle region (M). Among the seven citrus species screened here, C. limonia and C. reticulata showed the most discrepant values, with 39.7 and $62.8 \%$ of the microsatellites categorized as I, 28.7 and $17.6 \%$ as $\mathrm{M}$ and, 36.6 and $19.6 \%$ as E, respectively.

According to their potential as genetic markers, Temnykh et al. (2001) classified microsatellites of different sizes and types into two categories or groups: those larger than 20 repeated units (Class I); and those equal to or bigger than 12 but smaller than 20 repeated units (Class II). In this study, $31.0 \%$ of the EST-SSRs identified were classified as Class I while $69.0 \%$ were Class II. The sweet orange

Table 3 - Frequency distribution (\%) of the different SSR types (perfect repeats only) according to their potential as genetic markers. Definitions of these classes followed the pattern reported by Temnykh et al. (2001).

\begin{tabular}{|c|c|c|c|c|c|c|c|c|c|c|c|c|c|c|}
\hline & \multicolumn{2}{|c|}{ CA class } & \multicolumn{2}{|c|}{ CS class } & \multicolumn{2}{|c|}{ LT class } & \multicolumn{2}{|c|}{ CR class } & \multicolumn{2}{|c|}{ CG class } & \multicolumn{2}{|c|}{ CL class } & \multicolumn{2}{|c|}{ PT class } \\
\hline & I & II & I & II & I & II & I & II & I & II & I & II & I & II \\
\hline Mononucleotide & 0.82 & 0.75 & 0.60 & 0.66 & 0.88 & 0.81 & 0.66 & 0.69 & 0.76 & 0.74 & 0.95 & 0.94 & 0.81 & 0.82 \\
\hline Dinucleotide & 0.05 & 0.11 & 0.18 & 0.17 & 0.04 & 0.10 & 0.16 & 0.14 & 0.11 & 0.13 & 0.02 & 0.03 & 0.08 & 0.09 \\
\hline Trinucleotide & 0.08 & 0.14 & 0.15 & 0.18 & 0.05 & 0.08 & 0.13 & 0.17 & 0.09 & 0.14 & 0.02 & 0.03 & 0.09 & 0.10 \\
\hline Tetranucleotide & 0.03 & & 0.04 & & 0.02 & & 0.04 & & 0.02 & & 0.01 & & 0.02 & \\
\hline Pentanucleotide & 0.00 & & 0.01 & & 0.00 & & 0.00 & & 0.01 & & 0.00 & & 0.00 & \\
\hline Hexanucleotide & 0.01 & & 0.01 & & 0.01 & & 0.01 & & 0.01 & & 0.00 & & 0.01 & \\
\hline
\end{tabular}


showed the highest number of di- and trinucleotides in both classes (Table 3).

\section{Marker development and in silico polymorphism detection}

A list of 1,918 primer pairs were obtained from the MarkerXplorer pipeline. From these, 758 showed in silico polymorphism ranging from 2 to 10 -bp when analyzing sequences deposited into the CitEST database.

To validate microsatellite markers obtained from CitEST database using the MarkerXplorer pipeline, we synthesized 68 primer pairs which were used successfully to amplify PCR products of the expected size in accessions of Citrus spp. and the related genus Poncirus. Polymorphism was revealed by all primer pairs in the citrus genotypes tested. To analyze the potential of these markers for mapping studies, all functional loci were used in a Rangpur Lime vs. Citrumelo Swingle progeny. Twenty-two of these primer pairs $(32.0 \%)$ were able to reveal polymorphisms with allelic segregation for mapping (Figure 2).

\section{Functional annotation of the EST sequences containing SSRs}

Blast searches against the NCBI database were performed for each of the 68 clones that had primer pairs developed. Forty-three sequence $(63.2 \%)$ matches were

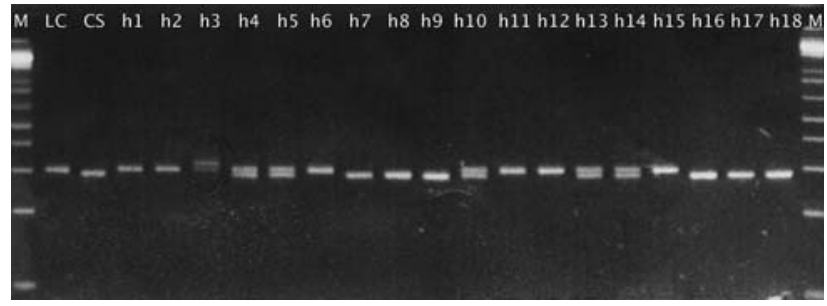

Figure 2 - Amplification for SSR derived from the CitEST database in Rangpur Lime (LC), Swingle Citrumelo (CS) and progeny (h1-h18). Molecular marker of $100 \mathrm{bp}(\mathrm{M})$.

identified with several known proteins, while 19 (27.9\%) had homology with expressed, hypothetical and unknown proteins from Arabidopsis thaliana, Cicer arietinum and Oryza sativa. Of the remaining sequences, six ( $8.8 \%)$ produced no hits with any known protein (Table 4).

The gene ontology categorization of the 62 sequences that showed some degree of homology revealed that 51 $(\sim 82 \%)$ of them had a protein match. From these, 40 $(82.3 \%)$ were homologous to proteins with molecular functions, mainly binding (DNA, RNA and ion), catalytic (protein kinase, lyase and hydrolase) and transporter activities (Figure 3). Forty-three (84.3\%) were homologous to proteins involved with the cellular component, mainly nucleus, organelles (chloroplast and mitochondrion) and membrane (Figure 3). Finally, $42(82.3 \%)$ were classified

Table 4 - Description of 68 ESTs-SSRs from the CitEST database.

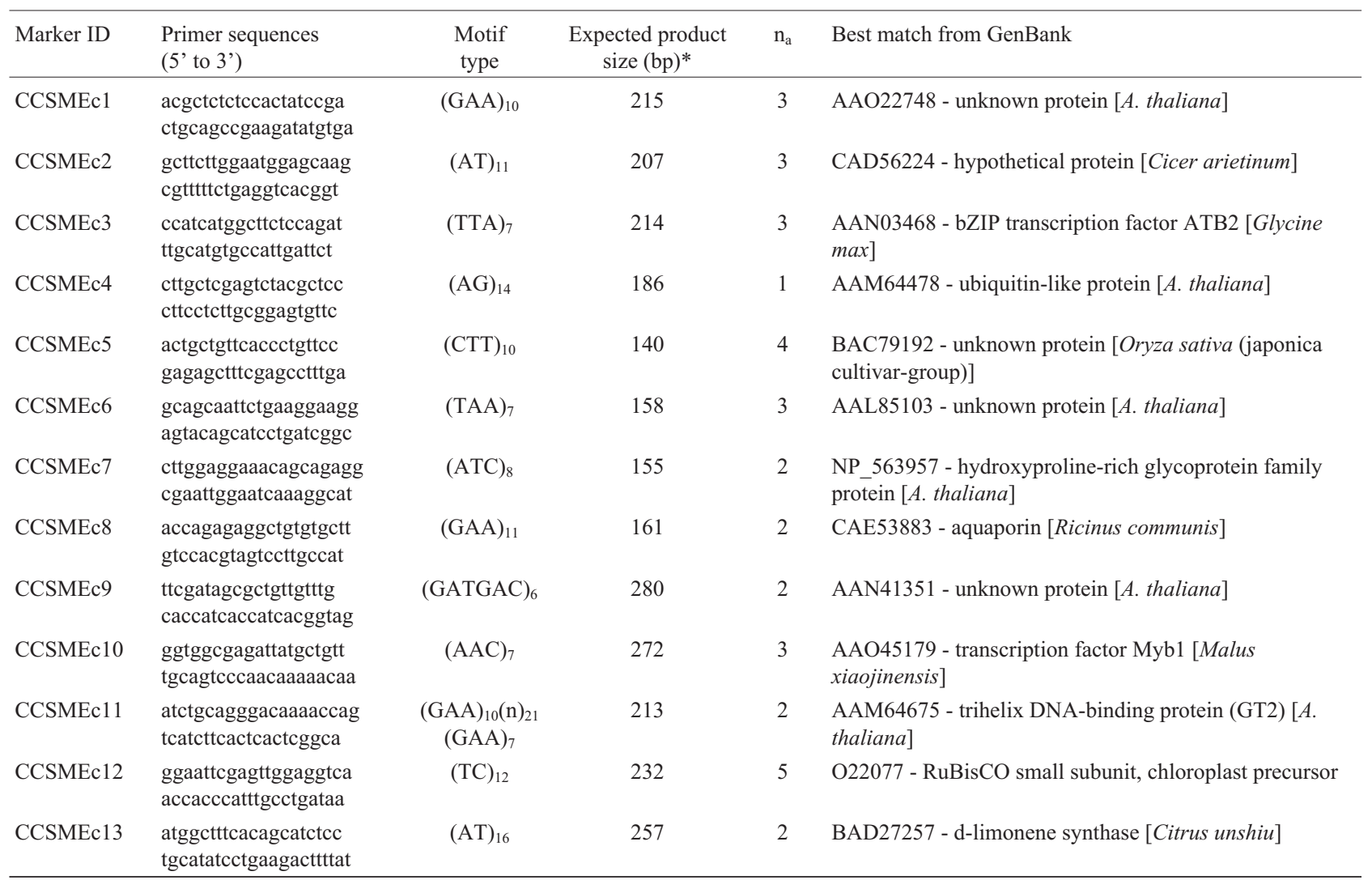


Table 4 (cont.)

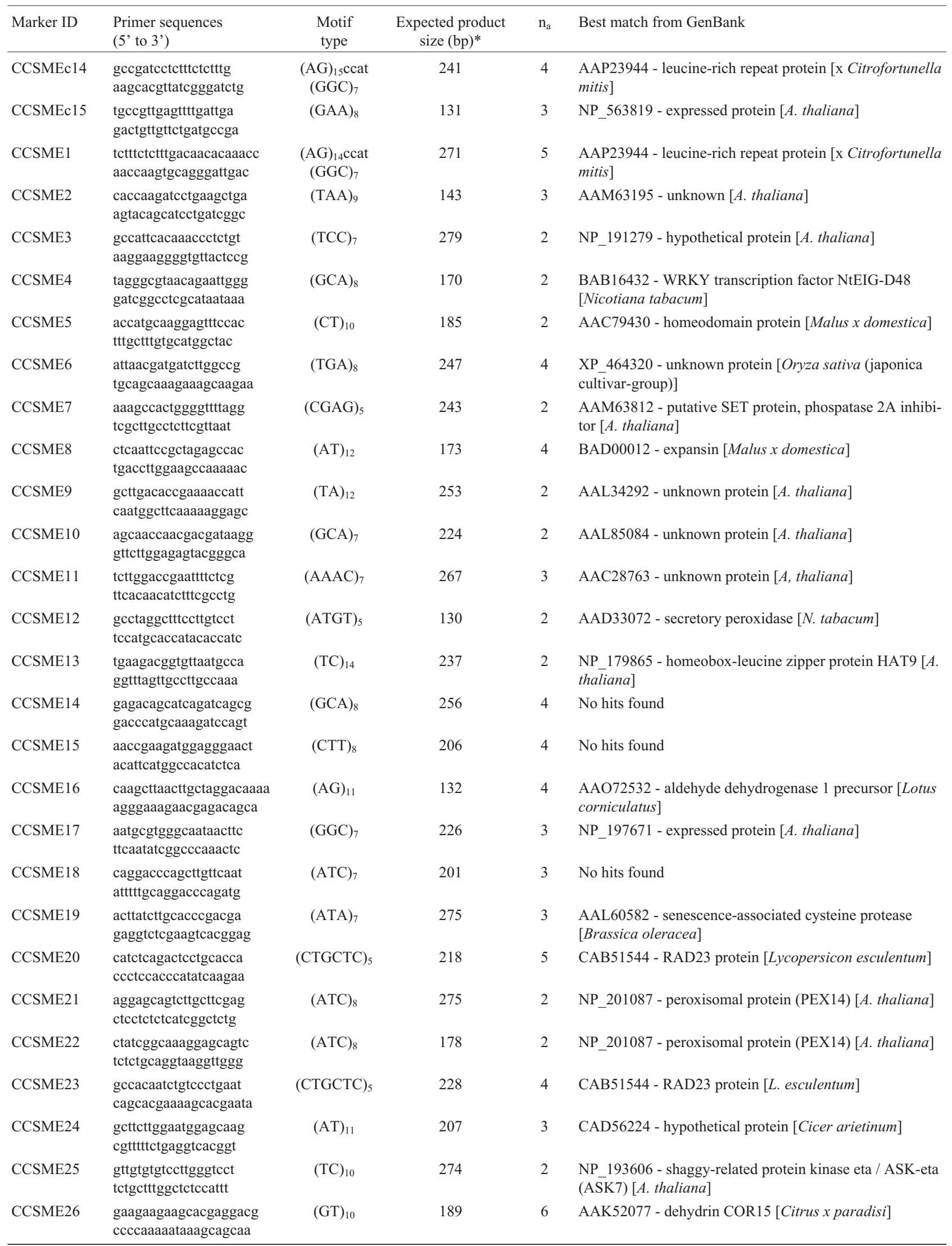


Table 4 (cont.)

\begin{tabular}{|c|c|c|c|c|c|}
\hline Marker ID & $\begin{array}{l}\text { Primer sequences } \\
\text { (5' to 3') }\end{array}$ & $\begin{array}{c}\text { Motif } \\
\text { type }\end{array}$ & $\begin{array}{l}\text { Expected product } \\
\text { size (bp)* }\end{array}$ & $\mathrm{n}_{\mathrm{a}}$ & Best match from GenBank \\
\hline CCSME27 & $\begin{array}{l}\text { gttttgcttgctttgtgtcg } \\
\text { caaacccatctaaagcccaa }\end{array}$ & $(\mathrm{ATAG})_{5}$ & 109 & 3 & AAP44415-40S ribosomal protein S9 [Lactuca sativa] \\
\hline CCSME28 & $\begin{array}{l}\text { aaaaagaacaggagcaggca } \\
\text { agaacccacatgcagaaacc }\end{array}$ & $(\mathrm{CGG})_{7}$ & 243 & 3 & NP_565233 - expressed protein $[$ A. thaliana $]$ \\
\hline CCSME29 & $\begin{array}{l}\text { accagagaggctgtgtgctt } \\
\text { gtccacgtagtccttgccat }\end{array}$ & $(\mathrm{GAA})_{11}$ & 161 & 2 & $\begin{array}{l}\text { AF141900 - putative aquaporin PIP2-2 [Vitis berlandieri } \\
\text { x Vitis rupestris] }\end{array}$ \\
\hline CCSME30 & $\begin{array}{l}\text { aatcaacggaaacaaatccg } \\
\text { ctaagctcaccaggctcacc }\end{array}$ & $(\mathrm{TCT})_{8}$ & 271 & 2 & $\begin{array}{l}\text { AAO72664 - wheat adenosylhomocysteinase-like protein } \\
\text { [O. sativa (japonica cultivar-group)] }\end{array}$ \\
\hline CCSME31 & $\begin{array}{l}\text { ggaattcgagttggaggtca } \\
\text { accacccatttgcctgataa }\end{array}$ & $(\mathrm{TC})_{12}$ & 230 & 4 & $\begin{array}{l}\text { AAG49562 - ribulose-1,5-bisphosphate carboxylase/oxy- } \\
\text { genase small subunit precursor [Citrus reticulata] }\end{array}$ \\
\hline CCSME32 & $\begin{array}{l}\text { ggtgcaaccactggaagaat } \\
\text { aagagcaaggggtttgtgtg }\end{array}$ & $(\mathrm{AT})_{10}$ & 190 & 3 & NP_568458 - expressed protein $[$ A. thaliana $]$ \\
\hline CCSME33 & $\begin{array}{l}\text { actgtccgatgaagctttgc } \\
\text { taaaatccgcttageccaaa }\end{array}$ & $(\mathrm{TC})_{12}$ & 279 & 3 & $\begin{array}{l}\text { AAG } 49562 \text { - ribulose-1,5-bisphosphate carboxylase/oxy- } \\
\text { genase small subunit precursor [Citrus reticulata] }\end{array}$ \\
\hline CCSME34 & $\begin{array}{l}\text { gagcaggccactttctcaac } \\
\text { aatagggecccacttgactt }\end{array}$ & $(\mathrm{GAGT})_{5}$ & 242 & 2 & $\begin{array}{l}\text { AAL } 91203 \text { - putative } \mathrm{C} 2 \mathrm{H} 2 \text {-type zinc finger protein }[A \text {. } \\
\text { thaliana }]\end{array}$ \\
\hline CCSME35 & $\begin{array}{l}\text { tgattactctgectccecct } \\
\text { tgcacagtcatgtctcctgg }\end{array}$ & $(\mathrm{GA})_{10}$ & 253 & 3 & $\begin{array}{l}\text { NP_ } 197570 \text { - senescence-associated protein -related }[A \text {. } \\
\text { thaliana }]\end{array}$ \\
\hline CCSME36 & $\begin{array}{l}\text { cgecatttgcttaggettt } \\
\text { gaaccetccagagttccetc }\end{array}$ & $(\mathrm{AG})_{10}$ & 220 & 3 & $\begin{array}{l}\text { NP_198801-40S ribosomal protein S9 (RPS9C) }[A \text {. } \\
\text { thaliana }]\end{array}$ \\
\hline CCSME37 & $\begin{array}{l}\text { atctcattctccatcgecac } \\
\text { ctctccattttgcetccaa }\end{array}$ & $(\mathrm{TC})_{11}$ & 244 & 2 & $\begin{array}{l}\text { Q39011 - Shaggy-related protein kinase eta (ASK-eta) }[A \text {. } \\
\text { thaliana }]\end{array}$ \\
\hline CCSME38 & $\begin{array}{l}\text { tgaaggctttttagagccga } \\
\text { aatagggeccacttgactt }\end{array}$ & $(\mathrm{GAGT})_{5}$ & 224 & 2 & No hits found \\
\hline CCSME39 & $\begin{array}{l}\text { tcctcgtctcaacacaaca } \\
\text { gaggctaatgcaagagaccg }\end{array}$ & $(\mathrm{CT})_{13}$ & 136 & 2 & CAB81454 - photosystem II protein W-like $[$ A. thaliana $]$ \\
\hline CCSME40 & $\begin{array}{l}\text { tgttgctgctgctcaaactt } \\
\text { tgaaactgaaaacaaaggattcaa }\end{array}$ & $(\mathrm{TA})_{12}$ & 106 & 6 & No hits found \\
\hline CCSME41 & $\begin{array}{l}\text { ttcatggcagcttgagtttc } \\
\text { agtcatggaagccaaaatgg }\end{array}$ & $(\mathrm{TC})_{12}$ & 250 & 4 & $\begin{array}{l}\text { AAM44082 - putative sorbitol transporter [Prunus } \\
\text { cerasus }]\end{array}$ \\
\hline CCSME42 & $\begin{array}{l}\text { gcagcaccaacaaagaatca } \\
\text { gaacgtacggggtcaaaaga }\end{array}$ & $(\mathrm{GCC})_{7}$ & 163 & 2 & AAM29150 - citrus sucrose transporter 1 [Citrus sinensis] \\
\hline CCSME43 & $\begin{array}{l}\text { gecgatcctctttctctttg } \\
\text { gttggatcccagctctgaag }\end{array}$ & $(\mathrm{AG})_{13}$ & 253 & 5 & $\begin{array}{l}\text { AAP23944 - leucine-rich repeat protein [x Citrofortunella } \\
\text { mitis] }\end{array}$ \\
\hline CCSME44 & $\begin{array}{l}\text { ttttggtttcatctgggtcc } \\
\text { cctcctgatgatgtcccact }\end{array}$ & $(\mathrm{TC})_{11}$ & 129 & 2 & $\begin{array}{l}\text { AAK } 92213 \text { - bZIP transcription factor BZI-2 [Nicotiana } \\
\text { tabacum }]\end{array}$ \\
\hline CCSME45 & $\begin{array}{l}\text { aagggttgttgctttggttg } \\
\text { ttcgctgaagagcatgtcac }\end{array}$ & $(\mathrm{GAA})_{8}$ & 196 & 4 & AAM63312 - unknown [A. thaliana $]$ \\
\hline CCSME46 & $\begin{array}{l}\text { tgctcttcggtgtcagagtg } \\
\text { cagccccaacaaaaacaact }\end{array}$ & $(\mathrm{AAC})_{7}$ & 257 & 2 & $\begin{array}{l}\text { AAO45179 - transcription factor Myb1 [Malus } \\
\text { xiaojinensis }]\end{array}$ \\
\hline CCSME47 & $\begin{array}{l}\text { agagcaacaaaaagtcccga } \\
\text { agggttgtggtaggatcacg }\end{array}$ & $(\mathrm{TCT})_{7}$ & 238 & 3 & NP_178346 - expressed protein $[$ A. thaliana $]$ \\
\hline CCSME48 & $\begin{array}{l}\text { ccatcatggettctccagat } \\
\text { tactccaattgcatgtccca }\end{array}$ & $(\mathrm{TTA})_{7}$ & 222 & 3 & No hits found \\
\hline CCSME49 & $\begin{array}{l}\text { aataagcgtatcagcagcagg } \\
\text { aatcatgaacgggctgaaac }\end{array}$ & $(\text { GTTGA })_{6}$ & 229 & 3 & $\begin{array}{l}\text { NP_195311 - Ras-related GTP-binding protein, putative } \\
{[\text { A. thaliana }]}\end{array}$ \\
\hline CCSME50 & $\begin{array}{l}\text { gagttgggattctgctgttga } \\
\text { gactgttgttctgatgecga }\end{array}$ & $(\mathrm{GAA})_{7}$ & 140 & 2 & NP_563819 - expressed protein $[$ A. thaliana $]$ \\
\hline CCSME51 & $\begin{array}{l}\text { tcattagctgattgccagga } \\
\text { aatgggaggatgcatggtaa }\end{array}$ & $(\mathrm{TA})_{12}$ & 216 & 4 & $\begin{array}{l}\text { NP_173866 - polcalcin, putative / calcium-binding pollen } \\
\text { allergen, putative }[\text { A. thaliana }]\end{array}$ \\
\hline CCSME52 & $\begin{array}{l}\text { ctggctcagctctgctcatt } \\
\text { tgctgctgcttctgcttcta }\end{array}$ & $(\mathrm{TC})_{14}$ & 182 & 2 & $\begin{array}{l}\mathrm{NP} \_178216 \text { - myb family transcription factor }[A \text {. } \\
\text { thaliana }]\end{array}$ \\
\hline CCSME53 & $\begin{array}{l}\text { gatctccetatcatcggcaa } \\
\text { ttttgagggetggatggata }\end{array}$ & $(\mathrm{TAA})_{11}$ & 187 & 3 & $\begin{array}{l}\text { T09875 - late embryogenesis-abundant protein Lea14-A - } \\
\text { upland cotton }\end{array}$ \\
\hline
\end{tabular}

*Expected product size (bp) estimated from the Primer3 program. $\mathrm{n}_{\mathrm{a}}$ : in silico polimorphism (number of alleles). 
as involved in biological processes such as cellular metabolism (nucleotide-excision repair, protein biosynthesis, protein amino acid phosphorylation and proteolysis), transcription (mainly regulation), transport (sucrose and carbohydrate), response to stimulus (oxidative stress, water and desiccation) and cell organization and biogenesis (Figure 3).

\section{Discussion}

The CitEST project has generated a large set of EST sequences from citrus, an excellent resource for rapid discovery of SSRs. Our study clearly illustrates that ESTs are a useful source of new SSR markers for citrus that are polymorphic and can be transferred between species and related genus. A number of reports have demonstrated that EST databases are a very good source of polymorphic markers for many organisms, including plants (Delseny et al., 1997; Scott et al., 2000; Kantety et al., 2002; Ceresini et al., 2005).

The MarkerXplorer pipeline used here was able to screen the CitEST data for all SSR motifs as well as to identify, in silico, a large number of primer pairs with a high potential for germplasm characterization and genetic mapping studies. Bioinformatics approaches are increasingly being used for molecular marker development since the se-

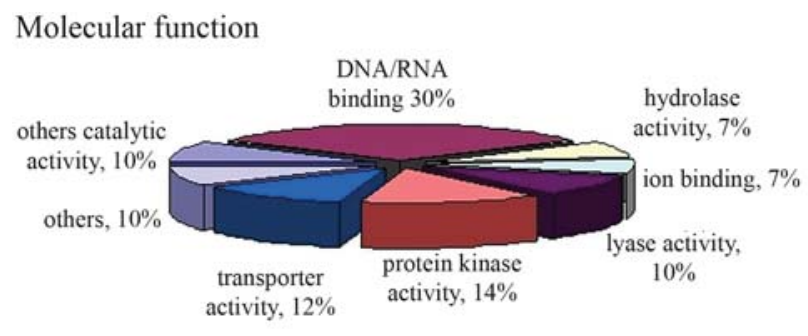

Cellular component
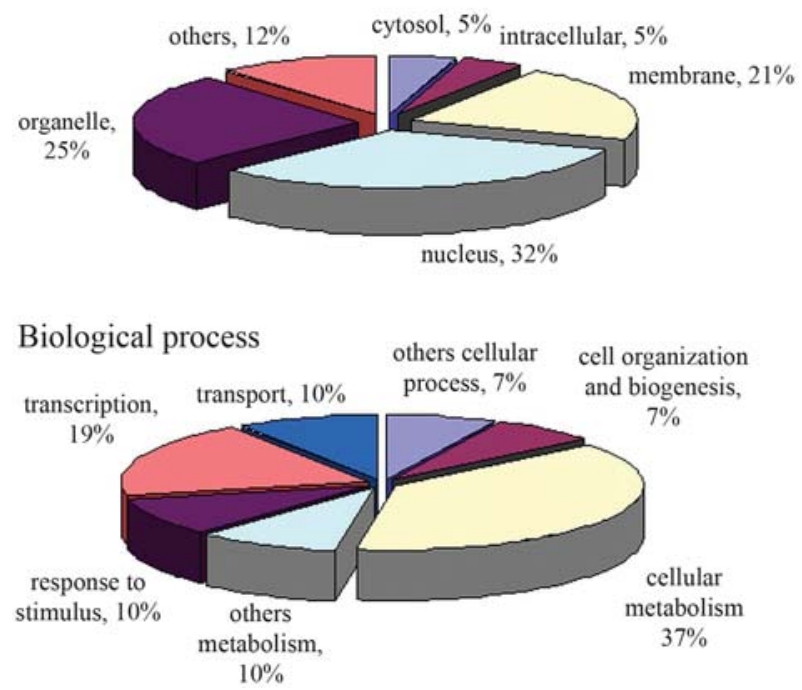

Figure 3 - Citrus EST-SSRs characterization as derived from Gene Ontology categories. quences from many genomes are made freely available in public databases (Kantety et al., 2002; Varshney et al., 2002). These sources are mined for SSRs using computational tools thereby eliminating the need for costly, laborious and time-consuming marker development.

Our results show that SSRs in the CitEST are highly abundant (33.3\%) when compared with others crops (Scott et al., 2000; Kantety et al., 2002). In other citrus databases, a frequency of $10.6 \%$ of EST sequences with at least one SSR was observed (Chen et al., 2006) and a total of $21.7 \%$ in citrus unigene analysis (Dong et al., 2006). Rangpur Lime was the species with the highest number of SSR motifs identified (64.7\%). This result should facilitate its use in mapping experiments geared toward molecular breeding. Sweet orange had highest number of sequences analyzed, but this fact was not reflected in a larger number of microsatellites detected.

The dinucleotides AG/CT were the most abundant microsatellites in EST sequences, which is consistent with previous surveys of SSR repeats in annual species, as described by Kantety et al., (2002) in comparative analysis using publicly available EST databases for barley, maize, rice, sorghum and wheat. In fact, this motif was also observed in perennial crops, such as eucalyptus (Ceresini et al., 2005), apple (Newcomb et al., 2006), strawberry (Folta et al., 2005) and citrus (Chen et al., 2006; Dong et al., 2006; Novelli et al., 2006). In general, the adenine-rich repeat motifs are most common in SSRs and, in the CitEST database, these motifs (AAG, AAT, AAAT, AAAG, AAAAT) were also the most abundant (Figure 1). Similar results were reached in others analysis of EST-SSRs in citrus (Chen et al., 2006; Dong et al., 2006) and apple (Newcomb et al., 2006). Additionally, trinucleotide repeats were representative among the different classes and showed the highest level of polymorphism in citrus species (data not show).

The origin and functional role of the microsatellites in expressed sequences are not well understood, but they presumably originate from single or multiple mutational events (Zane et al., 2002). Perfect SSRs were the most frequent type in our study, followed by compound and imperfect types. This suggests a certain degree of sequence stability and conservation in their recent evolution of citrus species. The exploration of perfect SSR in the CitEST database may be a valuable tool to study the evolution of proteins in citrus, since this SSR type is common in many proteins (Katti et al., 2000). Additionally, microsatellites loci with a high number of perfect repeats are usually more polymorphic (Weber, 1990).

The position where a SSR motif occurs in the EST sequence (middle region, 5' and 3' end) can influence the level of polymorphism of a marker (Scott et al., 2000). In our analysis, the 5' end region (I) showed the highest number of repeats, but the level of polymorphism among the species was not estimated in this study. 
High-quality amplification products were generated in all EST-SSRs evaluated in citrus species, many of which were polymorphic for at least one species, showing that EST sequences are a useful source of markers for Citrus and correlated genera and could therefore be related to agronomic important characters in genetic mapping.

Specific primer pair design from EST sequences on the CitEST database was more efficient when compared to primer design from the genomic libraries previously developed by our group (Novelli et al., 2000, 2006). However, we did not test the hypothesis that microsatellites derived from ESTs are less polymorphic than those derived from genomic libraries as demonstrated by several reports (Scott et al., 2000; Thiel et al., 2003).

The screening of EST-SSRs for polymorphism assessment using an $F_{1}$ progeny of the Rangpur Lime vs. Swingle Citrumelo cross revealed that 22 of the 68 amplified fragments revealed informative segregation configurations (Figure 2). The markers could be mapped in Rangpur Lime and Swingle Citrumelo according to the pseudotestcross strategy. This is an encouraging result considering that the number of informative SSR markers is still limited in citrus due to several characteristics related to the biology of these species (Chen et al., 2006; Novelli et al., 2006).

Despite the fact $82 \%$ of EST-SSRs markers presented herein showed homology with known gene products, no specific pattern of association to a specific component, process or function was detected. As observed in other works, the majority of transcripts detected represent enzymes of general metabolism (Ceresini et al., 2005; Folta et al., 2005, Newcomb et al., 2006). However, those transcripts related to biological processes such as response to biotic and abiotic stresses can now be readily mapped using existing populations.

In conclusion, our analysis revealed that our CitEST database is a valuable source for rapidly developing new SSR markers, highly transferable for diversity and mapping studies in citrus species and related genera. These data also could be applied in citrus breeding programs such as germplasm characterization, screening of zygotic and nucellar seedlings, and developing markers for marker-assisted selection.

\section{Acknowledgments}

We would like to thank all the members of the CitEST project and PADCT/CNPq for financial support. D.A.P. is a postdoctoral fellow funded by CNPq; V.M.N. is FAPESP postdoctoral fellow (Process n ${ }^{\circ} 04 / 11854-1$ ); M.C.Y. and M.A.M. are recipients of research fellowships from CNPq.

\section{References}

Altschul SF, Madden TL, Schäffer AA, Zhang J, Zhang Z, Miller W and Lipman DJ (1997) Gapped BLAST and PSI-BLAST:
A new generation of protein database search programs. Nucleic Acids Res 25:3389-3402.

Ashburner M, Ball CA, Blake JA, Botstein D, Butler H, Cherry JM, Davis AP, Dolinski K, Dwight SS, Eppig JT, et al. (2000) Gene ontology: Tool for the unification of biology. The Gene Ontology Consortium Nat Genet 25:25-29.

Cato SA, Gardner RC, Kent J and Richardson TE (2001) A rapid PCR-based method for genetically mapping ESTs. Theor Appl Genet 102:296-306.

Ceresini PC, Petrarolha Silva CLS, Missio RF, Souza EC, Fischer CN, Guillherme IR, Gregorio I, da Silva EHT, Cicarelli RMB, da Silva MTA, et al. (2005) Satellyptus: Analysis and database of microsatellites from ESTs of Eucalyptus. Genet Mol Biol 28:589-600.

Chen C, Zhou P, Choi YA, Huang S and Gmitter Jr FG (2006) Mining and characterizing from citrus ESTs. Theor Appl Genet 112:1248-1257.

Cristofani M, Machado MA, Novelli VM, Souza AA and Targon MLPN (2003) Construction of linkage maps of Poncirus trifoliata and Citrus sunki based on microsatellite markers. Proceedings of the $9^{\text {th }}$ International Society of Citriculture Congress, Orlando, USA, 1:175-178.

Delseny M, Cooke R, Raynal M and Grellet F (1997) The Arabidopsis thaliana $\mathrm{cDNA}$ sequencing projects. FEBS Lett 405:129-132.

Dong J, Guang-Yan Z and Qi-Bing H (2006) Analysis of microsatellites in citrus unigenes. Acta Genet Sinica 33:345-353.

Folta KM, Staton M, Stewart PJ, Jung S, Bies DH, Jesdurai C and Main D (2005) Expressed sequence tags (ESTs) and simple sequence repeat (SSR) markers from octoploid strawberry (Fragaria x ananassa). BMC Plant Biol 5:12.

Holton TA, Christopher JT, McClure L, Harker N and Henry RJ (2002) Identification and mapping of polymorphic SSRs markers from expressed gene sequences of barley and wheat. Mol Breeding 9:63-71.

Huang X and Madan A (1999) CAP3: A DNA sequence assembly program. Genome Res 9:868-877.

Kantety RV, La Rota M, Matthews DE and Sorrells ME (2002) Data mining for simple sequence repeats in expressed sequence tags from barley, maize, rice, sorghum and wheat. Plant Mol Biol 48:501-510.

Katti MV, Sami-Subbu R, Ranjekar PK and Gupta VS (2000) Amino acid repeat patterns in protein sequences: Their diversity and structural-functional implications. Protein Sci 9:1203-1209.

Kijas JMH, Fowler JCS, Garbett CA and Thomas MR (1994) Enrichment of microsatellites from the Citrus genome using biotinylated oligonucleotide sequences bound to streptavidin-coated magnetic particles. Biotechniques 16:657-662.

Murray MG and Thompson WF (1980) Rapid isolation of high molecular weight plant DNA. Nucleic Acids Res 8:43214325.

Newcomb RD, Crowhurst RN, Gleave AP, Rikkerink EHA, Allan AC, Beuning LL, Bowen JH, Gera E, Jamieson KR and Janssen BJ (2006) Analyses of expressed sequence tags from apple. Plant Physiol 141:147-166.

Novelli VM, Cristofani M and Machado MA (2000) Evaluation of microsatellite markers in cultivars of sweet orange (Citrus sinensis Osbeck). Acta Horticulturae 535:47-50.

Novelli VM, Cristofani M, Souza AA and Machado MA (2006) Development and characterization of polymorphic simple 
sequence repeats (SSRs) in sweet orange (Citrus sinensis L. Osbeck). Genet Mol Biol 29:90-96.

Rozen S and Skaletsky H (2000) Primer3 on the WWW for general users and for biologist programmers. In: Krawetz $\mathrm{S}$ and Misener S (eds) Bioinformatics Methods and Protocols in the Series Methods in Molecular Biology. Humana Press, Totowa, pp 365-386.

Schuler GD (1997) Sequence mapping by electronic PCR. Genome Res 7:541-550.

Scott KD (2001) Microsatellite derived from ESTs, and their comparison with those derived by other methods. In: Henry RJ (eds) Plant Genotyping: The DNA Fingerprinting of Plants. CABI Publishing, Oxon, pp 225-237.

Scott KD, Eggler P, Seaton G, Rossetto M, Ablett EM, Lee LS and Henry RJ (2000) Analysis of SSRs derived from grape ESTs. Theor Appl Genet 100:723-726.

Temnykh S, DeClerck G, Lukashova A, Lipovich L, Cartinhour S and McCouch S (2001) Computational and experimental analysis of microsatellites in rice (Oryza sativa L.): Fre- quency, length variation, transposon associations, and genetic marker potential. Genome Res 11:1441-1452.

Thiel T, Michalek W, Varshney RK and Graner A (2003) Exploiting EST databases for the development and characterization of gene-derived SSR-markers in barley (Hordeum vulgare L.). Theor Appl Genet 106:411-422.

Varshney RK, Thiel T, Stein N, Langridge P and Graner A (2002) In silico analysis on frequency and distribution of microsatellites in ESTs of some cereal species. Cell \& Mol Biol Letters 7:537-546.

Weber JL (1990) Informativeness of human (dC-dA)n (dG-dT)n polymorphisms. Genomics 7:524-530.

Zane L, Bargelloni L and Patarnello T (2002) Strategies for microsatellite isolation: A review. Mol Ecol 11:1-16.

\section{Internet Resource}

AmiGO Term browser, http://www.godatabase.org/cgi-bin/ amigo/go.cgi (December 15, 2006).

Associate Editor: Raquel Luciana Boscariol-Camargo 